\title{
Ambush Marketing in Poland Before the 2012 European Football Championship
}

\section{Marcin Gębarowski*}

\begin{abstract}
Activities belonging to ambush marketing (parasite marketing) are more and more widely undertaken with regard to subsequent, huge sports events. Therefore, this article analyzes the scope of using this form of promotion in the period that preceded the 2012 European Football Championship. A reference has been made to Polanda country which was a co-host of the championship. On the Polish market, owners of many brands performed actions that aimed at "stealing" image effects which should be achieved only by official sponsors who support such huge tournament (which is considered to be one of the three greatest sports events all around the worldapart from the Summer Olympic Games and the Football World Cup). The article has two objectives. First, it describes a concept of promoting selected brands (based on relation to the EURO 2012), identifying the scope of using ambush marketing forms in relation to Polish consumers. Second, it presents results of research which illustrates differences in conceiving the brands of both official sponsors and those - to whom one can attribute a name of ambushers.
\end{abstract}

Keywords: sports marketing, sponsoring, ambush marketing, UEFA, EURO 2012, Poland, football championship.

\section{Introduction}

Due to the fact that sport is more and more frequently used in marketing actions taken by market entities, numerous examples of using ambush marketing all over the world can be observed for many years. It is, however, still a new phenomenon in countries of Central East Europe, where the level of sports marketing diverges significantly from the one on the developed markets (e.g. in the USA or Western Europe).Therefore, after Poland had been awarded the rights to co-host the UEFA EURO in 2012, the analysed phenomenon attracted intense interest and its use increased on an unprecedented scale.

Poland and Ukraine - the co-hosts of the EURO 2012 - in the period that preceded the tournament, had to face many challenges. For the purpose of the championship, new football stadiums were constructed and the sports

* Marcin Gębarowski, Ph.D., Department of Marketing, Faculty of Management, Rzeszow University of Technology, al. Powstańców Warszawy 12, 35-959 Rzeszów, marcing@prz.edu.pl. 
infrastructure was prepared for team base camps. Moreover, an offer of hotels was considerably enhanced, airports and railway stations were modernised, new roads and motorways were built. Many services were prepared for the organisation of such a huge event. Also, a new dimension of marketing activity appeared - one of the phenomena that occurred in that time referred to a substantial increase of frequency of the actions which can be categorized as ambush marketing practices.

This article focuses on this form of marketing activity, which is related to sponsoring and carried out in order to associate an individual brand with a huge sports event that is broadcast by the media. However, this form of promotion is used by entities which are not official sponsors. The aim of this article is, first of all, to indicate the ideas which were used by ambushers in Poland in the period that preceded the EURO 2012, as well as to present the results of research which concerned the recognisability of the brands of official sponsors of the European Football Championship.

\section{The nature of ambush marketing and the areas of its analysis - literature review}

Ambush marketing appeared for the first time in the literature at the end of the 1980's - a few years after first instances of "stealing the image" of official sponsors of huge sports events had occurred. One of the very first definitions of the analysed phenomenon was given by Sandler and Shani (1989), who claimed that "this tactic involves the efforts of an organization to associate itself indirectly with an event in an effort to reap the same benefits as an official sponsor" (p. 9). At the same time, a synonymous term - parasite marketing - began to be used as well. In the following years there were attempts to define the analysed term more precisely - specifying it in both a narrow and a wide sense.

According to Schmitz (2005), in a narrow sense, ambush marketing refers to the direct efforts of one party to weaken or attack a competitor's official association with a sports organization acquired through the payment of sponsorship fees. In a broader sense, rather than such direct and intentional misrepresentation, ambush marketing refers to a company's attempt to capitalize on the goodwill, reputation, and popularity of a particular event by creating an association without the authorization or consent of the necessary parties. Some popular indirect ambush techniques include buying commercial time prior to and during event broadcasts, sponsoring the broadcasts of events rather than directly sponsoring the event, sponsoring individual teams and athletes, and using sporting events tickets in consumer giveaways, sweepstakes, or contests (p. 205). 
When defining the nature of ambush marketing, numerous examples were given, which presented its evolution. At present, the analysed phenomenon refers to the majority of global sports events, however, initially, ambush marketing was related to the Olympic Games (Shani and Sandler, 1998, pp. 369-371; Burton and Chadwick, 2009, p. 305). It is believed that the first instance of parasite marketing concerned the actions taken by an owner of the Kodak brand before the Summer Olympic Games held in Los Angeles in 1984 (Crow and Hoek, 2003). That was the first time when an official sponsor title was awarded, preserving the trade exclusivity right.

Some authors extended the definition of ambush marketing, referring the notion not only to sports events. Mazodier and Chandon (2012) maintained that ambush marketing can be defined as "the deliberate attempt, by a nonsponsor firm, to falsely suggest an association with an event, person or idea, for the purpose of deriving a commercial benefit from that association, without incurring the costs of the acquisition of sponsorship rights in relation to that event, person or idea" (p. 194). Sometimes, ambush marketing is also perceived as a manifestation of guerrilla marketing. However, taking into account the dissertations presented in this article, such expressions should be considered too broad.

The literature on the subject identified manifestations of parasite marketing many years ago. Meenaghan (1996) indicated five common ambush strategies: sponsoring media coverage of an event, sponsoring a subcategory within an event and exploiting the investment aggressively, making a sponsorship-related contribution to the "Players' Pool", planning advertising that coincides with the sponsored event, development of other imaginative ambush strategies (pp. 106-107). A newer and more detailed typology of ambush marketing, which is adequate for the reality of the contemporary market, has been also elaborated. Chadwick and Burton (2011) identified eleven types of ambush, ranging from the direct attack of one organization on a rival to the unintentional association of a company with an event due to reputation or past marketing efforts. They named the strategies as follows:

- predatory ambushing, coattail ambushing, property infringement ambushing, sponsor self-ambushing, associative ambushing, distractive ambushing, values ambushing, insurgent ambushing, parallel property ambushing, unintentional ambushing, saturation ambushing (pp. 715-716).

In the context of using practices which belong to ambush marketing it is worth mentioning that the ambushers' actions are very often facilitated by official sponsors themselves, who are not able to fully use the rights that they are entitled to, as well as they are incapable of emphasising the association 
of their brand with a particular event. Apart from purchasing a licence, it is also important to plan communication actions in a well-thought-out manner and make sufficient financial outlays available to perform those actions (Gębarowski, 2009, p. 23). Some authors pointed out detailed methods which counteract the practices used by the ambushers - regarding both sponsors and organisers of events. Meenaghan (1994), for instance, proposed the following actions to be performed by official sponsors: pressurizing event owners to protect their events, linking event and broadcast sponsorship, anticipating potential competitive promotions, exploiting the sponsorship rights secured, resorting to legal action (p. 84-85). Instructions in respect of reducing the phenomenon of ambush marketing can be found in many other publications (Payne, 1998; Shani and Sandler, 1998; Pitt, Parent, Berthon and Steyn, 2010; Chase and Kurnit, 2010; Gombeski, Wray and Blair, 2011). However, regardless of the nature and the scope of taken actions, ambushers are becoming smarter. Competitors, determined to create a false association between an event and their product or brand, are now capable of doing so without infringing or breaching trademark or intellectual property laws (Farrelly, Quester and Greyser, 2005, p. 342).

Many authors paid a lot of attention to legal aspects of the analysed phenomenon. For example, Townley, Harrington and Couchman (1998) concentrated on the practical and legal prevention of parasite marketing (in the short term as well as the long term). Ellis, Scassa and Séguin (2011) examined the emerging trend of host countries using legislation to protect the Olympic brand and control ambush marketing. Legal issues connected with the Olympic Games and other huge sports events were also described by Grady, McKelvey and Bernthal (2010) and Scassa (2011). Johnson (2011) and Louw (2012), on the other hand, in their extensive elaborations, very precisely characterised legal regulations - regarding parasite marketing which are in force in the United Kingdom and the European Union, as well as in selected countries from other continents (among others, in the USA, China, Brazil, Australia).

In the literature available so far, the attention has been devoted not only to legal determinants, but also to an ethical dimension of ambush marketing. Two of the first authors who described that problem were O'Sullivan and Murphy (1998). They identified and evaluated a range of possible actions to create more ethical commercial sponsorship.

An in-depth analysis of the phenomenon of ambush marketing in a different dimension - including psychological aspects - was carried out by Dalakas, Madrigal and Burton (2004). The authors focused on the motivation and the ability to process a persuasive communication in the context of using 
parasite marketing. On the other hand, Pitt et al. (2010), in their article, referred to cognitive mechanisms behind successful ambush marketing.

The fact that the phenomenon has been discussed in separate, coherent elaborations proves that it has been gaining a considerable significance. For instance, in one of his latest titles, Nufer (2013) identified in detail a theoretic basis for ambush marketing and presented numerous examples of its practical use. The author set forth the consequences of ambushers' activity in respect of different dimensions, as well as the methods of preventing their actions.

Ambush marketing is a phenomenon that has been observed for almost three decades. However, so far, there have been rather few elaborations in the literature (contrary to other areas of marketing activity), which mainly implied the nature of parasite marketing and its various forms. Also, ethical and legal dilemmas of the analysed marketing activity were discussed. Furthermore, numerous examples of using ambush marketing were presented. There are, however, not many elaborations that compare the knowledge, resulting from the actions taken with regard to the same sports events, of official sponsors' brands with ambushers' brands.

\section{Research methods}

In order to determine to what extent the official sponsors of the EURO 2012 and ambushers were associated with the European football championship, field research was conducted. It was carried out between the 17th of May and the 1st of June 2012, which was the period when broadcasting (exposure of) the commercials related to the analysed sports event increased. A method of collecting empirical data was a direct survey conducted with reference to a sample including 220 citizens of Podkarpackie Province. 49.5\% of respondents were women, and $50.5 \%$ - men. The sample did not involve random selection (nonprobability sampling) and it was carried out using a method of typical case sampling.

A fundamental research-related problem referred to how to indicate the extent to which the entities that use ambush marketing were associated with the European Football Championship - the EURO 2012. Also, researcher wanted to examine whether image results achieved by ambushers could be higher than the results of the promoting actions taken by the official sponsors of the event. In this context, the following research hypotheses have been formed:

- H1: brands employing ambush marketing may be more often recognized as sponsors of a football tournament than brands possessing the status of official sponsors of the event. 
- H2: being the sponsor of national teams or football associations may result in similar effects on a brand's image as being the official sponsor of the European Football Championship.

- H3: television is a medium most commonly associated with footballrelated advertisements.

The results of the field research are presented in the second part of this article. Moreover, the hypotheses were also verified in this part.

\section{The 2012 European Football Championship and its promotion potential}

Fourteen national teams, which had earlier won the promotion through a qualifying competition, and the two host countries of the tournament Poland and Ukraine, took part in the 2012 European Football Championship. The event was held for three weeks (from the 8th of June to the 1st of July), and 31 games were played in total. The tournament was organised on eight stadiums - four Polish (in Warsaw, Gdańsk, Poznań, Wrocław) and four Ukrainian (in Kiev, Kharkiv, Donetsk, Lviv). During the championship, the national teams were located at team base camps -13 of them were accommodated in Poland, and only 3 in Ukraine. The EURO 2012 was begun with the opening game between Poland and Greece, which was held at the newly built National Stadium in Warsaw. The final was played at the reconstructed Olympic Stadium in Kiev (Spain and Italy participated in the match).

The effects of organising such a huge event, like the EURO 2012, can be examined on many planes, including the measureable ones, such as, among other things, the development of infrastructure, the quantity of tickets sold for the games, numbers of incoming tourists after the end of the tournament. Marketing results which are more difficult to specify and which have translated into an image of the brands that support a competition are also important; among them one can point out, for example, a change of image of the country which hosts an event or a level and nature of sports competitionrelated emotions. As far as the last aspect regarding sponsors and ambushers is concerned, the most intriguing issue is an interest in the event expressed by fans and journalists - both in the period that preceded the tournament and during the time it was held. An audience rate of broadcast matches is relevant as well. With regard to that issue, it must be noted that during the EURO 2012 there were approx. 3.2 thousand journalists from all around the world in Poland, and the broadcast rights were purchased by 53 TV stations (the matches were broadcast across Europe and in 32 countries from other continents). Over 652 thousand fans directly saw the EURO 2012 games that were played at four Polish stadiums. Nielsen Audience Measurement indicates 
that an average TV audience of all tournament matches in Poland equalled to 7.5 million viewers, which constituted $51 \%$ of shares in the television market (http://media2.pl/euro2012/93685-Euro-2012-w-TVP-Srednio-75mln-widzow-122-mln-zl-z-reklam.html). An important place for a promotion of brands that were official partners of the tournament were - apart from the mass media - stadiums and so called fan zones, where the official sponsors had exclusive rights to exhibit their graphic signs and sell products. The fan zones were constructed in the centres of largest cities, where crowds of fans gathered. Over 3 million people visited all Polish zones (in Warsaw, Poznań, Gdańsk, Wrocław and (racow).

On the basis of these figures one can consider the European Championship to be the event which, apart from the Olympic Games and the Football World Cup, is the most vulnerable to using ambush marketing. This is because such championship has characteristics that increase the probability that the analysed phenomenon will happen - it is: a tournament, an international and media event (broadcast in many countries), which is eagerly watched by spectators and viewers, and is spatially concentrated (takes place at stadiums) and organised cyclically (Waśkowski, 2009, p. 10).

Organisers of huge sports events attempt to protect sponsors' rights and privileges. That was also the case with Union of European Football Associations (UEFA) and the EURO 2012. The future co-hosts of the tournament - Poland and Ukraine - had to accept the obligations set forth by the UEFA, which protect the interest of this organisation in respect of both legal and financial aspects. The Polish government undertook, among other things, to protect signs and other intellectual property rights indicated by the UEFA, as well as to prevent unfair marketing practices and forbidden actions during the sales of tickets. Furthermore, the tournament organiser itself registered specified trademarks - device (graphic) marks, word marks and combination marks. The prohibition of using some signs and phrases was introduced - among other things, graphic mark of the championship or a name "EURO UEFA 2012" (they could be used only under licence agreements concluded with the UEFA). However, even though such regulations were implemented, it was still legally permitted to use elements that had the association with football and the championship itself - that is, for example, expressions like "2012" and "championship", national flags, symbols of a ball and stadiums, an image of fans. 


\section{Marketing activities of official sponsors of the European Football Championship and other market entities' actions related to ambush marketing}

Ten brands were the official sponsors of the tournament which was organised in 2012 in Poland and Ukraine: Adidas, Canon, Castrol, CocaCola, Continental, Hyundai-Kia, Carlsberg, McDonald's, Sharp, Orange. Apart from global partners, the EURO 2012 was supported also by domestic sponsors - in Poland, the following brands were involved: Bank Pekao SA, E. Wedel, MasterCard. Owners of the majority of those brands in the period that preceded the European Football Championship undertook intense and various promotional actions in order to inform fans about the fact that they were assigned an official sponsor status and to create association with this event. For example, Coca-Cola was the first brand, which a few months before the championship placed advertisements in the media referring to football symbols. Castrol used commercials with a slogan "We can do it", which was a local adaptation of the global campaign "That calls for a Carlsberg!". Another brand - Continental - was advertised by a short TV spot, which informed that it was a sponsor of the championship. Hyundai in its marketing actions presented a specially prepared - particularly on the occasion of the championship - price offer for cars. Fans and present football players of the Polish national team appeared in the commercials of Orange, and Jerzy Dudek (a former Polish goalkeeper) became a Castrol's ambassador, which was announced in commercials. A promotional campaign for McDonald's included a slogan "McDonald's Player Escort", which was given a considerable media support. Jakub Błaszczykowski - the Poland's national team captain was involved in the campaign. McDonald's project was a contest for children, in which the main prize was an opportunity to walk together with players onto a pitch just before the tournament games. With regard to Adidas, in the media there frequently appeared the information that its product called "Tango 12" would be the official ball of the EURO 2012. Many official sponsors organised contests, in which everyone could win a ticket for the EURO 2012 matches - such as Castrol, Sharp and Orange. Moreover, products contained in packaging with the graphic sign of the championship were introduced into the Polish market - for example, Coca-Cola and Wedel.

The biggest and the most expensive EURO 2012-related marketing project, implemented by a non-sponsor, was a campaign entitled "the Fifth Stadium". The promotional campaign concerned Tyskie beer, and the idea behind it referred to support together and "create the biggest stadium all around the world". During three months (from the beginning of April to the end of the championship), Polish Television (TVP) broadcast on its three channels 60 episodes of the series entitled "the Fifth Stadium". The plot of 
each three-minutes-long episode referred directly to the football subject and the EURO 2012. It was set in a pub, where a logotype of beer was presented (product placement was applied). Many communication channels were used in the campaign (ATL, BTL, ambient media), including, among other things, TV commercials, in which famous footballers took part: Luis Figo, Marco van Basten and Zbigniew Boniek. The "Fifth Stadium" project was continued also in 2013 when the Polish national team played further games.

Not only Tyskie, but also many other brands used advertisements (in all kinds of the media) in Poland to evoke associations with the EURO 2012. Such examples include the TV commercials of certain brands, which were broadcast in that time very often, for instance, Danio (the story was set on a pitch of a stadium), Tesco (a character from the commercial wore a scarf in the colours of the national team), Hoop Cola (a group of fans in front of the TV were shown). Also, advertising slogans followed a sports convention - for example, "We do not sponsor football stars! We do sponsor fans!" (Media Markt), "A masterly offer for the champions!" (Stihl). One of the ideas was to use a voice of a sports commentator - which was implemented by the owner of a chain of supermarkets Lidl into one of his television spots. It should be added that ambush marketing was manifested through the involvement of popular Poland national players by some non-sponsors. For instance, in promotion of Lay's crisps and Pepsi drinks an image of Maciej Szczęsny was used, and Rober Lewandowski appeared in Gillette commercials.

Before the European Championship, many products in the colours of the national (red and white) flag and including football motifs were introduced to Polish shops. A universal image of a football (a white ball with black markings) was used the most frequently. Those signs were placed on the packaging of such brands as: Tymbark drinks, Wawel chocolate bars, Sokołów cold cuts, Grafenwalder beer. The signs mentioned above were very often complemented with slogans (for example, "Score prizes") or product names introduced in the context of the championship (for example, "A fan's sausage", "A fan's chocolate bar"). Hochland brand offered consumers processed cheese called "the red and white". Even the products themselves adopted national colours - the owner of Tic-Tac brand launched red and white drops contained in single small boxes.

A separate group of brands, which were not official sponsors of the EURO 2012 - but many people still associated them with the tournament, were the brands that supported Polish national team under the agreements concluded before with the Polish Football Association (PZPN). The status of "Official Polish National Team Sponsor" was given then to: Nike (shoes, clothes and sports accessories), Biedronka (a chain of supermarkets), Warka (beer) and Cisowianka (mineral water). In promotion of these brands the signs reserved 
by the UEFA were not used, yet the rights obtained as a result of co-operation with PZPN constituted the basis for promotion - among other things, the logo of the Polish organisation, as well as the image of players and national team kits were used (for example, Jakub Błaszczykowski acted in commercials of Biedronka). In the campaigns there were also slogans that referred to the tournament or football: "United in combat" (Nike), "We are all the national team" (Biedronka), "Official mineral water of the Polish national team" (Cisowianka). Warka brand ran a campaign entitled "To the anthem!". It encouraged fans to visit a specially created Internet website and record their own performance of the Polish anthem. Furthermore, there was a bus that travelled across the country and served as a mobile recording studio.

The actions described above relate to ambush marketing carried out in respect of the association dimension, which entails creating associations of a brand with a sports event using diversified forms of marketing activity. Such actions, which are based on more or less direct relation to football, are difficult to eliminate by applying legal regulations. Association ambush marketing was carried out both in the period that preceded the 2012 EURO and later on - during the championship. There is also a more uncommon form of the analysed phenomenon - aggressive ambush marketing, which is slightly different. It can occur during an event and entails exhibiting the brand that is not an official sponsor within the area of a sports venue (it happens the most often through the actions performed by athletes or fans), as well as in the vicinity of it. Such conduct is usually subject to stringent restrictions that can be imposed by an organiser of the event. An example of this type of behaviour took place in 2012, when a Danish player, Nicklas Bendtner, right after scoring a goal for his team in the game against Portugal in Lviv, lifted his jersey to expose the logo of an Irish bookmaker company - Paddy Power. For his conduct, he was punished by the UEFA with a 100,000 euro fine and suspended for one national team match (the owner of the brand that was promoted by the player undertook to pay the levied fine).

\section{Awareness of the EURO 2012 official sponsors' brands and the entities that use ambush marketing - an empirical perspective}

The participants of the research were asked to point out the brands which in their opinion - were the official sponsors of the EURO 2012 championship. However, the awareness of the sponsors was defined using the following two approaches - unprompted and prompted. Initially, the respondents were not suggested any answers and they were requested to indicate by themselves at most 13 sponsors (that was the exact number of the EURO 2012 supporting brands in Poland -3 of them on the national level and 10 on the global 
one). Subsequently, with regard to the research that could help determine the prompted recall, the same respondents were given a list of 36 items to point out at most 13 sponsors. They could choose from those names of the brands whose commercials, presented in the media at that time, based on the associations with football.

Concerning the first part of the research, the most frequently indicated brands were - Coca-Cola (62\%) and Biedronka (58\%). Other brands were chosen much more rarely, and they included such names as: Carlsberg (34.0\%), McDonald's (31.1\%), Tyskie (26.4\%), Warka (25.9\%), Wedel (23.1\%), Cisowianka (19.3\%), Hyundai-Kia (13.7\%), Orange (11.8\%). The percentage of indications for the other brands did not exceed $10 \%$. As far as the part relating to unprompted recall of sponsors is concerned, Coca-Cola $(85.6 \%)$ and Biedronka (70.4\%) were also the most often repeated answers given by the respondents. On the other hand, a slightly lower level of indications was attained by: Carlsberg (67.6\%) and McDonald's (64.4\%). Subsequent places were occupied by: Tyskie (51.4\%), Warka (50.0\%), Wedel (46.3\%), Adidas (41.2\%), MasterCard (38.9\%), Cisowianka (38\%), Hyundai-Kia (36.1\%), Orange (35.6\%). Regarding other brands which were also covered by the research, unprompted recall did not exceed $30 \%$ (Table 1).

Table 1. Brands indicated as the sponsors of the UEFA 2012 Football Championship

\begin{tabular}{lccccc}
\hline Brand & $\begin{array}{c}\text { Unprompted } \\
\text { recall } \\
(\mathbf{N = 2 1 2})^{*}\end{array}$ & $\begin{array}{c}\text { Prompted } \\
\text { recall } \\
\mathbf{( N = 2 2 0 )}\end{array}$ & Brand & $\begin{array}{c}\text { Unprompted } \\
\text { recall (N=212)* }\end{array}$ & $\begin{array}{c}\text { Prompted } \\
\text { recall } \\
\text { (N=220) }\end{array}$ \\
\hline Coca-Cola & $62.3 \%$ & $85.6 \%$ & PGE & $2.4 \%$ & - \\
Biedronka & $58.0 \%$ & $70.4 \%$ & Samsung & $1.9 \%$ & $8.3 \%$ \\
Carlsberg & $34.0 \%$ & $67.6 \%$ & Lidl & $1,4 \%$ & - \\
McDonald's & $31.1 \%$ & $64.4 \%$ & Media Markt & $1.4 \%$ & $6.5 \%$ \\
Tyskie & $26.4 \%$ & $51.4 \%$ & Nałęczowianka & $1.4 \%$ & - \\
Warka & $25.9 \%$ & $50.0 \%$ & Toyota & $1.4 \%$ & - \\
Wedel & $23,1 \%$ & $46,3 \%$ & Canon & $1.4 \%$ & $7.4 \%$ \\
Cisowianka & $19.3 \%$ & $38.0 \%$ & Tymbark & $1.4 \%$ & $6.9 \%$ \\
Hyundai-Kia & $13.7 \%$ & $36.1 \%$ & MasterCard & $0.9 \%$ & $38.9 \%$ \\
Orange & $11.8 \%$ & $35.6 \%$ & Orlen & - & $24.1 \%$ \\
Adidas & $9.9 \%$ & $41.2 \%$ & Gillette & $0.5 \%$ & $18.5 \%$ \\
Cappy & $7.5 \%$ & - & T-Mobile & - & $13.4 \%$ \\
Sharp & $7.5 \%$ & $21.3 \%$ & Continental & - & $12.0 \%$ \\
Castrol & $7.1 \%$ & $19.4 \%$ & Red Bull & $0.5 \%$ & $11.1 \%$ \\
Lech & $5.7 \%$ & - & BZ WBK & - & $9.3 \%$ \\
Heineken & $4.2 \%$ & $23.6 \%$ & Tesco & - & $6.9 \%$ \\
Pepsi & $3.8 \%$ & $17.1 \%$ & Hoop Cola & $0.5 \%$ & $6.0 \%$ \\
& & & & & \\
\hline
\end{tabular}




\begin{tabular}{lccccc}
\hline Lay's & $3.3 \%$ & $26.4 \%$ & Kinder & - & $4.2 \%$ \\
Nike & $2.4 \%$ & - & Real & $0.5 \%$ & $3.2 \%$ \\
Plus & $2.4 \%$ & $8.3 \%$ & PLL LOT & - & $2.3 \%$ \\
DB Schenker & $2.4 \%$ & - & Nivea & - & $0.9 \%$ \\
Bank PKO SA & $2.4 \%$ & $9.7 \%$ & Hochland & - & $0.0 \%$ \\
\hline
\end{tabular}

* $\mathrm{N}$ is a number other than 220 due to the fact that 8 respondents did not point out names of the sponsors.

Research participants were also inquired about which mass media presented commercials that referred to football most often. The most frequent response concerned television (94.5\%) and the Internet (73.4\%). Other responses referred to: the radio $(40.8 \%)$, billboards next to roads $(28.9 \%)$, everyday newspapers (16.5\%), magazines (12.4\%), the cinema (3.7\%).

The research also contained references to packaging - treated as a tool applied to evoke the associations with the European Football Championship. The vast majority $-86.8 \%$ - of respondents noticed football motifs on the packaging of diversified products. The brand which in this aspect was the most frequently indicated by the people under the research was Coca-Cola $-38.7 \%$ of respondents admitted that they saw the symbols referring to the EURO 2012 on labels of these drinks. Football-related elements were also noticed on the packaging of products offered by the following brands: Wedel (22.5\%), Tyskie (17.8\%), Cisowianka (9.9\%), Warka (9.9\%), Carlsberg (7.9\%), Biedronka (7.9\%), Pepsi (7.3\%), Lay's (5.8\%), McDonald's (3.7\%).

Pursuant to the UEFA requirements, using the official championship logo in marketing actions was permissible only for the official sponsors of the event**. Therefore it was reasonable to examine to what extent the symbol of the EURO 2012 was recognisable. The majority of inquired people (64.5\%) claimed that they knew what the logo of the European Football Championship, organised in Poland and Ukraine, looked like. However, merely $46.8 \%$ of the sample under research were able to correctly describe the graphic sign of the tournament. The remaining $17.7 \%$ of the respondents defined it inappropriately (for instance, some of them mistook the championship logo for official mascots - the creatures called Slavek and Slavko). Every third person (35.5\%) revealed that they did not pay attention to what the EURO 2012 symbol looked like.

\section{Discussion and conclusion}

The results show that using ambush marketing practices in a well-thoughtout manner can be effective and produce notable image outcomes leading to

\footnotetext{
** The symbol of the European Football Championship in 2012 was a plant whose flower was a football, and on its both sides - two leaves (goblets) grew from the stem, which were in the national colours of Poland (red and white) and Ukraine (yellow and blue).
}

Entrepreneurship in Tourism and Sport, M. Bednarczyk, J. Gancarczyk (Eds.) 
a situation when a particular brand will be strongly associated with a popular sports event. That is proved, first of all, by the case of the brands of beer Tyskie and Warka. Their owners - Kompania Piwowarska and Grupa Żywiec, respectively - used original and large-scale promoting actions. As a result, Tyskie and Warka were indicated by half of the respondents as official sponsors of the EURO 2012 (in the part which defined the prompted recall). Slightly higher percentage of indications was attained by the real partner of this event-Carlsberg. One can therefore notice that the brands which use the actions considered as parasite marketing for the purpose of their promotion can be more recognisable than a brand of an official sponsor (which confirms the first hypothesis).

The participants of the conducted survey very frequently mentioned such brands as Biedronka and Cisowianka, which obtained the status of the Polish national team sponsors (they were not, however, the official sponsors of the tournament). Their intense promoting actions, which were based on the opportunities resulting from the fact that they were partners of the football association - including a utilisation of the PZPN logo and images of players, led to creating strong associations with the EURO 2012 (hence, the second research hypothesis is confirmed). Biedronka, a chain of supermarkets, was the second most popular indication - following Coca-Cola, and before all other official sponsors of the European Football Championship.

Basing on the results of the analysis, another conclusion can be reachedconfirming the third hypothesis and indicating that the main medium used to form a relation between a brand and sports event, was television. However, a significant role in this respect was played by a marketing activity performed on the Internet. Moreover, the packaging of products constituted a relevant means of creating associations with the tournament.

Furthermore, the research revealed that in the period that preceded a huge sports event, in a mass of many advertisements referring to football motifs, it was difficult to be a recipient and distinguish the ambushers' advertisements from those advertisements which included an official event sign and information indicating that a particular brand is an official sponsor. In this context, it is worth noticing that merely less than a half of the research participants were able to correctly describe a graphic sign of the tournament organised in Poland and Ukraine.

The analysis of marketing actions taken in connection with the European Championship allowed to indicate main manifestations of ambush marketing, used in Poland in 2012. Ambushers' activity concerned, first of all, performance of the following actions in order to promote their brands:

- involving national team players - yet without showing them in official, reserved kits of the Polish team, 
- using the symbols referring to the most popular sports discipline (it manifested through placing in commercials or on packaging of products, among other things, an image of: football, goals, pitches, stadiums, etc.),

- using an arrangement of white and red colours, which were very common during the championship in the public area and created the association with the national flag,

- referring to fans, who were deeply emotionally engaged in experiencing the championship (commercials based on the scenes which presented people who supported the national team).

It must be mentioned that the research, whose results have been presented in this article, was limited in its nature. However, it can be considered as an introduction to large-scale examinations that will be carried out in the periods preceding future huge sports events. With regard to the subsequent examinations, one should make an attempt to specify to what extent the actions perceived as parasite marketing influence a level of product sales achieved by ambushers. It is also vital to identify the factors that determine the effectiveness of marketing based on "stealing associations", and, what is more relevant, to decide whether the analysed form of marketing activity-due to ethical and legal reasons - should be considered a permissible technique of fighting for a customer in the extremely competitive contemporary economy.

\section{References}

Burton, N., Chadwick, S. (2009). Ambush marketing in sport: An analysis of sponsorship protection means and counter-ambush measures. Journal of Sponsorship, 2(4), 303-315.

Chadwick, S., Burton, N. (2011). The evolving sophistication of ambush marketing: A typology of strategies. Thunderbird International Business Review, 53(6), 709-7 19.

Chase, Ch. R., Kurnit, R. (2010). Fighting for what is left of exclusivity: Strategies to protect the exclusivity of sponsors in the sports industry. Journal of Sponsorship, 3(4), 379-393.

Crow, D., Hoek, J. (2003). Ambush marketing: A critical review and some practical advice. Marketing Bulletin, 14, 1-14.

Dalakas, V., Madrigal, R., Burton, R. (2004). Understanding ambush marketing: Implications of information processing. In: L. R. Kahle, Ch. Riley (Eds.), Sports Marketing and the Psychology of Marketing Communication (pp. 293-304), Mahwah: Lawrence Erlbaum Associates.

Ellis, D., Scassa, T., Séguin, B. (2011). Framing ambush marketing as a legal issue: An Olympic perspective. Sport Management Review, 14, 297-308. 
Farrelly, F., Quester, P., Greyser, S. A. (2005). Defending the co-branding benefits of sponsorship B2B partnerships: The case of ambush marketing. Journal of Advertising Research, 45(3), 339-348.

Gębarowski, M. (2009). Ambush marketing - identyfikacja zjawiska w kontekście dużych wydarzeń sportowych. Marketing i Rynek, 5, 19-23.

Gombeski, Jr. W., Wray, T., Blair, G. (2011). Prepare for the Ambush!. Marketing Healthcare Services, 31(2), 24-28.

Grady, J., McKelvey, S., Bernthal, M. J. (2010). From Beijing 2008 to London 2012: Examining event-specific Olympic legislation vis-à-vis the rights and interests of stakeholders. Journal of Sponsorship, 3(2), 144-156.

Johnson, Ph. (2011). Ambush Marketing and Brand Protection. Oxford: Oxford University Press.

Louw, A. M. (2012). Ambush Marketing and the Mega-event Monopoly: How Laws are Abused to Protect Commercial Rights to Major Sporting Events. The Hague: T.M.C. Asser Press.

Mazodier, M., Quester, P., Chandon, J.L. (2012). Unmasking the ambushers: conceptual framework and empirical evidence. European Journal of Marketing, 4(1), 192-214.

Meenaghan, T. (1994). Point of view: ambush marketing: immoral or imaginative practice? Journal of Advertising Research, 34(3), 77-88.

Meenaghan, T. (1996). Ambush marketing - a threat to corporate sponsorship. Sloan Management Review, 38, 103-113.

Nufer, G. (2013). Ambush Marketing in Sports. Abingdon: Routledge.

O'Sullivan, P., Murphy, P. E. (1998). Ambush marketing: The ethical issues. Psychology \& Marketing, 15(4), 349-366.

Payne, M. (1998). Ambush marketing: The undeserved advantage. Psychology \& Marketing, 15(4), 323-331.

Pitt, L., Parent, M., Berthon, P., Steyn, P.G. (2010). Event sponsorship and ambush marketing: Lessons from the Beijing Olympics. Business Horizons, 53(3), 281-290

Sandler, D. M., Shani, D. (1989). Olympic sponsorship vs "ambush" marketing: Who gets the gold? Journal of Advertising Research, 29, 9-14.

Scassa, T. (2011). Ambush marketing and the right of association: Clamping down on references to that big event with all the athletes in a couple of years. Journal of Sport Management, 25(4), 354-370.

Schmitz, J. K. (2005). Ambush marketing: The off-field competition at the Olympic Games. Northwestern Journal of Technology and Intellectual Property, 3(2), 203-208.

Shani, D., Sandler D. M. (1998). Ambush marketing: Is confusion to blame for the flickering of the flame? Psychology \& Marketing, 15(4), 367-383.

Townley, S., Harrington, D., Couchman, N. (1998). The legal and practical prevention of ambush marketing in sports. Psychology \& Marketing, 15(4), 333-348. 
Waśkowski, Z. (2009). Ambush marketing - alternatywa dla sponsoringu sportowego. Zeszyty Naukowe, 7, (pp. 5-11). Ostrołęka: Wyższa Szkoła Społeczno-Ekonomiczna w Ostrołęce.

\begin{abstract}
Abstrakt (in Polish)
Aktywność zaliczana do ambush marketingu (parasite marketingu) jest coraz szerzej podejmowana w odniesieniu do kolejnych, dużych wydarzeń sportowych. W zwiqzku $z$ tym $w$ artykule przeanalizowano zakres wykorzystania tej formy promocji w okresie poprzedzajqcym mistrzostwa Europy w piłce nożnej w 2012 roku. Odniesiono się do Polski - kraju będqcego współgospodarzem tych mistrzostw. Na polskim rynku właściciele wielu marek zrealizowali działania majqce na celu „kradzież" efektów wizerunkowych, które powinni uzyskiwać tylko oficjalni sponsorzy wspierajqcy tak duży turniej (uznawany z jednq z trzech największych imprez sportowych na świecie - obok letnich igrzysk olimpijskich oraz mistrzostw świata w piłce nożnej). Cel artykułu jest dwojaki. Po pierwsze, opisano koncepcje promowaniu wybranych marek (bazujqce na zwiqzkach z EURO 2012), identyfikujq̨c zakres wykorzystania form ambush marketingu w odniesieniu do polskich konsumentów. Po drugie, zaprezentowano wyniki badania obrazujq̨cego różnice w postrzeganiu zarówno marek będqcych oficjalnymi sponsorami, jak również tych - którym można przypisać zastosowanie ambush marketingu.
\end{abstract}

Słowa kluczowe: marketing sportowy, sponsoring, ambush marketing, UEFA EURO 2012. 